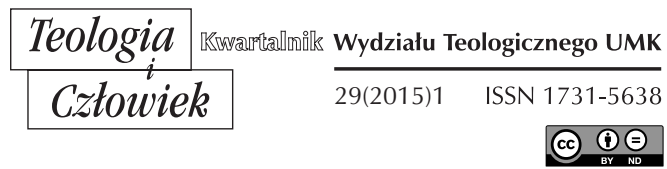

KS. KONRAD GLOMBIK*

OPOLE

\title{
GŁÓWNE RYSY SYLWETKI DUCHOWEJ BŁ. KS. JERZEGO POPIEŁUSZKI
}

DOI: http://dx.doi.org/10.12775/TiCz.2015.002

Postać bł. ks. Jerzego Popiełuszki doczekała się już kilku poważnych opracowań, zawierających jego biografię. Również akta z procesu dotyczącego jego zamordowania przedstawiają różne wątki z jego życia

* Prezbiter diecezji opolskiej, dr hab. teologii, kierownik Katedry Teologii Moralnej i Duchowości na Wydziale Teologicznym w Uniwersytecie Opolskim.

1 Zob. G. Sikorska, A Martyr for the Truth. Jerzy Popietuszko, London 1985; R. Boyes, J. Moody, The Priest Who Had to Die. The Tragedy of Father Jerzy Popietuszko, London 1986; A. Lewek (oprac.), Męczennik prawdy i nadziei, Warszawa 1986; P. Raina, Ks. Jerzy Popiełuszko. Męczennik za wiarę i ojczyznę, t. I-II, Olsztyn 1990; P. Nitecki, Znak zwycięstwa. Ksiądz Jerzy Popiełuszko (1947-1984), Wrocław 1991; Z. Malacki, Stuga Boży ksiądz Jerzy Popiełuszko (1947-1984), Warszawa 2002; E.K. Czaczkowska, T. Wiścicki, Ksiądz Jerzy Popiełuszko, Warszawa 2004; M. Kindziuk, Świadek prawdy. Życie i śmierć księdza Jerzego Popiełuszki, Częstochowa 2004; P. Burgoński, C. Smuniewski, Ksiądz Jerzy Popiełuszko, syn, kapłan, męczennik, Warszawa 2010; P. Janowski, Popiełuszko Jerzy, EK, t. XV, Lublin 2011, kol. 1418-1420; J. Kopiec, Popiełuszko Jerzy, LThK, t. VIII, Freiburg im Br. 2006, kol. 420; P. Nitecki, „Z miłości umarteś...” O miłości Ojczyzny i Kościoła w czasach komunizmu w dwudziestolecie męczeństwa ks. Jerzego Popiełuszki, AK 143(2004), nr 3, 
i charakteryzują jego postać, a także wydarzenia z jego życia. Biografia i faktografia dotyczące jego osoby, na którą składa się wiele wątków, jest mocno złożona, a dla jej rzetelnego przedstawienia niezbędne były badania licznych dokumentów i świadectw. Inną ciekawą, aczkolwiek podobnie złożoną kwestią jest adekwatne przedstawienie sylwetki duchowej znanego na całym świecie kapłana zamordowanego przez funkcjonariuszy Służby Bezpieczeństwa. Nie pozostawił on po sobie testamentu duchowego, a zapiski i kazania, zawierające wiele oryginalnych myśli, pozwalają jedynie pośrednio na zarysowanie istotnych cech duchowości ich autora.

$\mathrm{Na}$ fakt, że postać bł. ks. Jerzego Popiełuszki charakteryzuje specyficzna duchowość, wskazują słowa Jana Pawła II wypowiedziane we Włocławku. Mówiąc o zamordowanym kapłanie, Papież stwierdził, że „nie wolno go traktować tylko jako sługę pewnej sprawy w porządku politycznym, chociaż była to sprawa do głębi etyczna. Trzeba go widzieć i czytać w całej prawdzie jego życia. Trzeba go czytać od strony tego wewnętrznego człowieka, o którego prosi Apostoł w Liście do Efezjan. Tylko ten właśnie człowiek wewnętrzny mógł być świadkiem; takim świadkiem naszych trudnych czasów, naszego ostatniego dziesięciolecia, jakim był"².

Prezentując sylwetkę duchową postaci znanej z historii najnowszej, należy mieć świadomość, że chodzi o to, co związane jest $\mathrm{z}$ religijnym wymiarem życia człowieka, jego odniesieniem do Boga, kształtowanym i realizowanym w oparciu na nauce, przykładzie i dziele zbawczym Jezusa Chrystusa, a obejmujące różne przejawy życia, wchodzące w zakres etosu chrześcijańskiego, religijności, ascezy i mistyki³. W przypadku kapłana diecezjalnego duchowość jest wyraźnie określona przez związane z tą posługą głoszenie słowa Bożego i sprawowanie sakramentów świętych.

s. 427-433; G. Bartoszewski, Obraz życia i działalności ks. Jerzego Popiełuszki w świetle jego „Zapisków” (1980-1984), AK 143(2004), nr 3, s. 459-475; A. Lewek, Kaznodziejstwo patriotyczne ks. Jerzego Popiełuszki, AK 143(2004), nr 3, s. 476-493; T. Kaczmarek, Jan Paweł II wobec świadectwa ks. Jerzego Popiełuszki, AK 143(2004), nr 3, s. 494-507; A. Lewek, Bibliografia ks. Jerzego Popiełuszki, AK 143(2004), nr 3, s. 536-550.

2 Jan Paweł II, Nie pozwól się uwikłać siłom pożądania, które sa w tobie jako „zarzewie grzechu”. Homilia wygłoszona podczas Mszy św. odprawionej na lotnisku Aeroklubu (Włocławek, 7 VI 1991), w: tenże, Bogu dziękujcie, Ducha nie gaście. Czwarta wizyta duszpasterska w Polsce 1-9 czerwca 1991 roku, Watykan 1991, s. 194-195.

3 Zob. M. Daniluk, Duchowość chrześcijańska, EK, t. IV, Lublin 1985, kol. 317. 
Słusznie jest ks. Popiełuszko zaliczany do grona kapłanów określanych jako z ludzi wziętych i dla ludzi całkowicie poświęconych aż do ofiary z życia ${ }^{4}$, dobrych pasterzy - świadków Chrystusa Zmartwychwstałego ${ }^{5}$, symbolu miłości i wierności Chrystusowi ${ }^{6}$ oraz „heroicznego świadka piękna i prawdy Ewangelii Jezusa" . Zamierzeniem niniejszego artykułu jest syntetyczne ukazanie wiodących specyficznych rysów sylwetki duchowej bł. ks. Jerzego Popiełuszki, które wyłaniają się z analizy jego życiorysu, zachowanych notatek, udzielonych wywiadów i wygłoszonych homilii, a także świadectw o nim osób, które go znały. Do istotnych elementów sylwetki duchowej tego bohaterskiego kapłana należy jego postawa głębokiej wiary i zawierzenia Bogu, niezłomnej nadziei, niestosowania przemocy i sprzeciwu, a także społeczne konsekwencje wyznawanej wiary.

\section{CZłOWIEK GŁĘBOKIEJ WIARY}

Biskup Opolski Alfons Nossol w specjalnej odezwie z 3 XI 1984 r. skierowanej do diecezjan w związku ze śmiercią ks. Jerzego Popiełuszki odniósł do jego osoby słowa Pisma świętego: „Dusze sprawiedliwych są w ręku Boga i nie dosięgnie ich męka” (Mdr 3,11), a także fragment z Liturgii Godzin: „Oto mąż Boży, który aż do śmierci walczył w obronie prawa Bożego; nie bał się gróźb prześladowców, bo Chrystus był jego mocą"8. Powyższe słowa charakteryzują postać bł. ks. Jerzego

4 Jan Paweł II, „Nie kradnij” znaczy takize nie nadużywaj twojej władzy nad własnością. Homilia wygłoszona podczas Mszy św. beatyfikacyjnej Matki Bolesławy Lament (Białystok 5 VI 1991), w: tenże, Bogu dziękujcie, Ducha nie gaście. Czwarta wizyta duszpasterska $w$ Polsce 1-9 czerwca 1991 roku, s. 137.

${ }^{5}$ G.L. Müller, Homilia wygłoszona podczas Mszy świętej ku czci św. Stanisława (Kraków 12 V 2013), www.doctrinafidei.va/muller/rc_con_cfaith_doc_20130512_omelia-crcocvia_pl.html [dostęp 6 X 2014].

6 T. Bertone, Homilia podczas udzielania sakramentu bierzmowana w parafii $w$ Straszynie (1 V 2009), www.vatican.va/roman_curia/secretariat_state/card-bertone/2009/documents/rc_seg-st_20090501_confermazione [dostęp 6 X 2014].

7 A. Amato, Homilia podczas beatyfikacji ks. Jerzego Popiełuszki (Warszawa 6 XI 2010), OsRomPol 31(2010), nr 7, s. 60.

8 A. Nossol, Odezwa z 3 XI 1984 r. w związku ze śmiercią księdza Jerzego Popiełuszki, Archiwum Kurii diecezjalnej w Opolu, L.dz. 26/84. 
Popiełuszki jako człowieka wiary, której podstawą była osobista więź z Bogiem.

Trudno jest szczegółowo dokonać opisu doświadczenia i przeżywania osobistej więzi człowieka z Bogiem, będącej istotnym wymiarem postawy wiary. Ks. Jerzy Popiełuszko w opisywaniu tego doświadczenia był dość powściągliwy. W jego listach i zapiskach można znaleźć pewne wątki świadczące o jego głębokiej wierze, związanych z nią doświadczeniach i formach jej wyrażania i przeżywania. Z okresu odbywania przez niego służby wojskowej w liście do ojca duchownego z 19 I 1967 r. pisał m.in. o uczestnictwie we Mszy św. i nowennie do Matki Bożej Nieustającej Pomocy, rozmyślaniu i czytaniu książeczki Naśladowanie Chrystusa, a także wspólnej modlitwie, różańcu, drodze krzyżowej i recytowaniu Mszy św. w święta, co w ówczesnych uwarunkowaniach było związane z szykanami ${ }^{9}$.

O podobnych formach praktyk religijnych pisał kleryk Popiełuszko w liście z lutego 1967 r. Wspomina w nim jednak o szykanach, które go z tej racji spotkały ze strony władz wojskowych. Jego postawę wiary wyraża uwaga dotycząca przesłuchania, w której stwierdził: „Rzeczywiście, chłopaki wspólnie odmawiali różaniec. Ja zbywałem go [dowódca plutonu] raczej milczeniem, odmawiając modlitwy w myśli i ofiarując cierpienia, powodowane przygniatającym ciężarem plecaka, maski, broni i hełmu Bogu, jako przebłaganie za grzechy. Boże, jak się lekko cierpi, gdy się ma świadomość, że się cierpi dla Chrystusa"10.

Jeszcze wyraźniej postawę wiary i zawierzenia Bogu wyraził Jerzy Popiełuszko w liście do rodziców, napisanym w jednostce wojskowej w Bartoszycach 26 VI 1967 r. Wspominając o trudnych chwilach, stwierdził: „Trzeba pamiętać, że kogo Bóg bardziej doświadcza w cierpieniach, tego bardziej też kocha. W każdym utrapieniu trzeba szukać woli Bożej, dlatego w Bogu trzeba szukać spokoju. Najpierw w cichej modlitwie, w poleceniu wszystkiego, co się robi Bogu. W świecie, na tym padole łez, jest już tak, że każdy cierpi. Nie ma ludzi, którzy by nie mieli jakichś przykrości, jakichś zmartwień. My mamy zmartwienia w wojsku, Wy ma-

9 J. Popiełuszko, Zapiski, listy i wywiady 1967-1984, G. Bartoszewski (oprac.), Warszawa 2010, s. 23-24.

${ }^{10}$ Tamże, s. 26-27. 
cie w domu. I dlatego nie trzeba się nigdy złościć z żadnego cierpienia. Teraz są już wakacje. Byłbym już w domu, całe trzy miesiące, gdyby nie to wojsko. Ale widocznie Bogu się podobało, żebym był razem z innymi w wojsku. Za to również trzeba dziękować Bogu. Bo nie ma tego złego, co by na dobre nie wyszło" ${ }^{11}$. Te sformułowania wyrażają prostą, ale zarazem głęboką wiarę bł. Jerzego Popiełuszki, którą wyrażała postawa odniesienia życia $\mathrm{z}$ jego trudnościami do Boga, a jednocześnie zawierzenia, które polegało na interpretacji wydarzeń życia z perspektywy Opatrzności Bożej, a także zgodą z wolą Bożą.

Postawę zawierzenia ks. Jerzego Popiełuszki Bogu wyrażają zapiski sporządzone przez niego w grudniu 1983 r., w sytuacji, kiedy wobec jego osoby były kierowane ze strony władz niesłuszne oskarżenia dotyczące prowokacji w jego mieszkaniu, a ze strony władzy kościelnej zarzuty dotyczące zaniedbania duszpasterstwa służby zdrowia. Stan swego ducha wyraził wówczas, pisząc m.in.: „[...] zarzuty mi postawione zwaliły mnie z nóg. SB na przesłuchaniu szanowało mnie bardziej. Nie jest to oskarżenie. Jest to ból, który uważam za łaskę Bożą, do lepszego oczyszczenia się i przyczynek do większych owoców mojej pracy. [...] Boże, jak wielkie doświadczenie mi dajesz, ale jednocześnie dajesz mi tyle sił i ludzkiej życzliwości"12.

W następnych dniach zanotował: „Boże, dzięki Ci za ten czas rekolekcji, który mi ofiarowałeś. Za możliwość umocnienia się Tobą i większego jeszcze włączenia Ciebie w moje, nasze sprawy. Niech Imię Twoje będzie błogosławione. [...] Dzisiaj przed obiadem o 12.00 poszedłem odmówić różaniec w kościele na chórze. Błogosławiona cisza. Nad amboną złoty krzyż. Od czasu do czasu wpadał promyk słońca i krzyż rozjaśniał się złotą, ciepłą poświatą. Potem następował mrok. Boże, jak bardzo podobne jest ludzkie życie, szare, trudne, czasami ponure i byłoby często nie do zniesienia, gdyby nie promyki radości, Twojej obecności, znaku, że jesteś z nami, ciągle taki sam, dobry i kochający"13.

O postawie wiary i zawierzenia życia Bogu świadczy także notatka zamieszczona w sytuacji, kiedy opisywał fakty związane $\mathrm{z}$ oskarżeniami

\footnotetext{
11 Tamże, s. 30-31.

12 J. Popiełuszko, Zapiski 1980-1984, Paryż 1985, s. 47-48.

13 Tamże, s. 48-49.
} 
kierowanymi pod jego adresem i przesłuchaniami. Napisał wtedy: „Ostatnie dni były pełne napięcia. Ale Bóg daje siłę. Jak łatwo jest znosić przeciwności i przez nie się oczyszczać, gdy jest pewność, że z nami jest Bóg"14.

Zgodnie ze świadectwami osób, które znały bł. ks. Jerzego Popiełuszkę, jego głęboka wiara była miarą dla wszystkich jego czynów, pomagała mu przyjmować trudności i nieprzyjemności. Szczególnie uprzywilejowanym miejscem przeżywania spotkania z Bogiem była dla niego Eucharystia. Udział we Mszy św. dodawał mu mocy i umacniał w dawaniu świadectwa wierze. Głęboka wiara ks. Jerzego Popiełuszki oddziaływała i promieniowała na innych. Często jego spotkania z ludźmi stawały się okazją do modlitwy ${ }^{15}$. Bł. ks. Jerzy Popiełuszko wspominał o tym w swoich zapiskach, stwierdzając: „Bogu Najwyższemu dzięki, że pozwala mi być tym, który pomaga młodzieży przybliżyć się do siebie, a we wspólnej modlitwie do Chrystusa"16. Na innym zaś miejscu zanotował: „Wczoraj przyszedł człowiek, który nie był 34 lata u spowiedzi, bo dzięki Mszy za Ojczyznę i mojej obecności w sądach, na nowo odnalazł się w Kościele. Jak wiele potrafisz, Boże, zdziałać przez tak niegodne jak ja stworzenie. Dzięki Ci Panie, że mną się posługujesz" ${ }^{17}$.

\section{CZłOWIEK NIEZłOMNEJ NADZIEI}

Z wiarą i zawierzeniem, które charakteryzują sylwetkę duchową ks. Jerzego Popiełuszki, wiąże się kolejna jego postawa, jaką jest nadzieja. Pisząc o nadziei, należy mieć świadomość, że ogólnie chodzi o postawę chrześcijanina, który oczekuje spełnienia się obietnic Bożych, a jej zasadniczym przedmiotem jest odnowienie w Chrystusie zmartwychwstałym zarówno rodzaju ludzkiego, jak i całego wszechświata, czyli przemiana i uzdrowienie świata poddanego złu i zepsuciu oraz ostateczne wybawienie z grzechu, cierpienia i śmierci przez zmartwychwstanie i usynowienie

14 Tamże, s. 49.

15 A. Amato, Homilia podczas beatyfikacji ks. Jerzego Popiełuszki (Warszawa 6 XI 2010), s. 59-60.

16 J. Popiełuszko, Zapiski 1980-1984, s. 29.

17 Tamże, s. 32. 
w Chrystusie ${ }^{18}$. Jak zauważył papież Benedykt XVI, nadzieja „[...] jawi się jako element wyróżniający chrześcijan fakt, że oni mają przyszłość: nie wiedzą dokładnie, co ich czeka, ale ogólnie wiedzą, że ich życie nie kończy się pustką. Tylko wtedy, gdy przyszłość jest pewna jako rzeczywistość pozytywna, można żyć w teraźniejszości. [...] Kto ma nadzieję, żyje inaczej; zostało mu dane nowe życie" ${ }^{19}$.

Analizując zapiski i kazania ks. Jerzego Popiełuszki, można te ogóle podstawowe stwierdzenia o istocie nadziei odnieść do jego osoby. Świadczy o tym m.in. notatka sporządzona w listopadzie 1983 r., kiedy władze miały zamiar aresztować kilku księży, w tym ks. Jerzego Popiełuszkę, w związku z odprawianiem Mszy św. za ojczyznę. Ks. Popiełuszko napisał wówczas: „Liczę się z tym, że mogą mnie internować, mogą aresztować i spreparować skandal, ale nie mogę przecież zaprzestać tej działalności, która jest służbą Kościołowi i Ojczyźnie”20. Podobny wydźwięk ma notatka sporządzona kilka dni później. Czytamy tam: „Dzisiaj byłem w Kurii. Dowiedziałem się, że wczoraj z Komendy Głównej wpłynęła na mnie skarga, że wielokrotnie już przestrzegano i jeżeli się moje postępowanie nie zmieni, zachowają się w stosunku do mnie zgodnie $\mathrm{z}$ dekretem o stanie wojennym. Cóż może się zmienić w moim postępowaniu? Nie mogę przecież przestać służyć ludziom"21. Postawa nieustraszenia, o której mówią powyższe zapiski, wynikała z przekonania ks. Popiełuszki, że służy dobrej sprawie, która pomimo niejasności i trudności ma szansę na powodzenie.

Inna wzmianka ukazująca ks. Popiełuszkę jako człowieka nadziei jest związana $\mathrm{z}$ przesłuchaniem dotyczącym materiałów znalezionych w jego mieszkaniu. W obliczu powagi oskarżeń ks. Popiełuszko zapisał: „Pan jednak dał siłę. Przyjąłem to spokojnie. Zacząłem się śmiać i powiedziałem: »Panowie przesadziliście«"22.

18 Por. K. Rahner, H. Vorgrimler, Mały słownik teologiczny, tł. T. Mieszkowski, P. Pachciarek, Warszawa 1987, kol. 255-257; T. Sikorski, A. Zuberbier, Nadzieja, w: A. Zuberbier (red.), Słownik teologiczny, t. I, Katowice 1985, s. 337-341.

19 Benedykt XVI, Encyklika o nadziei chrześcijańskiej „Spe salvi”, Watykan 2007, nr 2 .

20 J. Popiełuszko, Zapiski 1980-1984, s. 28.

21 Tamże, s. 30.

22 Tamże, s. 45. 
Jeszcze wyraźniej charakteryzują ks. Popiełuszkę jako człowieka niezachwianej nadziei teksty wygłaszanych kazań, w których powtarza się wątek nadziei $\mathrm{w}$ odniesieniu do powodzenia odrodzenia się narodu i zwycięstwa idei solidarności. W homilii wygłoszonej 29 VIII 1982 r., nawiązując do wprowadzenia stanu wojennego i delegalizacji „Solidarności”, ks. Popiełuszko powiedział m.in.: „Co można powiedzieć dzisiaj, w drugą rocznicę - którego już z rzędu? - patriotycznego zrywu społeczeństwa polskiego? Co można powiedzieć dzisiaj, gdy w grudniową noc ubiegłego roku w sposób gwałtowny i bolesny zostało złamane porozumienie z Wybrzeża i Śląska? Gdy został zadany cios, zadana rana, która przecież ciągle jeszcze krwawi. Nie jest to rana śmiertelna, bo nie można zadać rany śmiertelnej temu, co nieśmiertelne. Nie można uśmiercić nadziei. A »Solidarność« była i jest nadzieją wielu Polaków, nadzieją tym silniejszą, im bardziej jest ona zespolona z Bogiem przez modlitwę. "Solidarność« $\mathrm{w}$ narodzie rozrosła się jak mocne drzewo, które chociaż jest podcięte w swych korzeniach, wypuszcza nowe. I chociaż drzewem tym szarpią burze, chociaż urwano mu koronę chwały, to ono nadal trzyma się mocno ziemi ojczystej i czerpie z naszych serc i naszej modlitwy ożywcze soki, które pozwalają mu trwać i w końcu wydać dobry owoc"23.

W przekonaniach i kaznodziejstwie ks. Jerzego Popiełuszki wyjątkowym znakiem nadziei na zwycięstwo i przezwyciężenie bólu, cierpienia, udręki fizycznej i duchowej jest krzyż Chrystusa, w którym wszystko to znajduje sens. To, że krzyż jest znakiem nadziei oznacza, że ludzie aresztowani, niesłusznie skazani, internowani, poniżani w swojej godności, pozbawieni pracy upodabniają się w sposób szczególny do cierpiącego Chrystusa, który umarł na krzyżu za całą ludzkość, pokonał śmierć i otworzył drogę do Zmartwychwstania ${ }^{24}$. Śmierć Jezusa na krzyżu nie była, jak zakładali ci, którzy Go skazali na śmierć, klęską, ale zwycięstwem, a krew Chrystusa przelana na krzyżu stała się źródłem zbawienia i otworzyła ludzkości powrót do domu Ojca w królestwie niebieskim. Obowiązek budowania królestwa prawdy, miłości, sprawiedliwości i po-

${ }^{23}$ J. Popiełuszko, Kazania 1982-1984 wygłoszone w kościele św. Stanisława Kostki $w$ Warszawie, Warszawa 2010, s. 43; podobne myśli zawiera homilia wygłoszona 28 VIII 1983 r., zob. tamże, s. 120.

24 Tamże, s. 47-48. 
koju mają ci, którzy zawarli z Chrystusem przymierze przez sakrament chrztu świętego ${ }^{25}$.

W powyższych stwierdzeniach zawarta jest swoista teologia nadziei, która oparta jest na tajemnicy krzyża. Myśl tę kontynuował ks. Popiełuszko w tej samej homilii słowami: „Dzięki śmierci i zmartwychwstaniu Chrystusa symbol hańby i poniżenia stał się symbolem odwagi, męstwa, pomocy i braterstwa. W znaku krzyża ujmujemy dziś to, co najbardziej piękne i wartościowe w człowieku. Przez krzyż idzie się do Zmartwychwstania. Innej drogi nie ma. I dlatego krzyże naszej Ojczyzny, krzyże nasze osobiste, naszych rodzin, muszą doprowadzić do zwycięstwa, do Zmartwychwstania, jeżeli łączymy je z Chrystusem, który krzyż pokonał"26.

Ksiądz Jerzy Popiełuszko, będąc człowiekiem niezłomnej nadziei, której wyrazem jest tajemnica krzyża, wskazywał w swoim kaznodziejstwie na jej wymiar społeczny. W swoich homiliach zachęcał do bycia silnym miłością, męstwem i nadzieją. Oznacza to przekonanie, że nie da się wymazać z dziejów narodu ważnych wydarzeń, do których należy uchwalenie Konstytucji 3 maja, ale także założenie Solidarności. Mają one swoje znaczenie dla życia narodu, dążenia do tożsamości i kształtowania jego przyszłości. Niektórzy mogą interpretować wydarzenia przeszłości jako przegraną, zbędne walki albo niepotrzebne narażanie się. Należy jednak wierzyć, że nadejdą czasy, kiedy bezowocne dzisiaj wysiłki i trudy będą owocowały dla dobra Ojczyzny ${ }^{27}$. Nadzieję wyrażają także słowa ks. Popiełuszki o nadejściu czasu, kiedy w Ojczyźnie brat nie będzie z nienawiścią podnosił ręki na brata, więzieni za przekonania powrócą do swoich domów i będą mogli bez ograniczeń angażować się na rzecz ojczyzny, zostaną przywróceni do pracy ci, których bez powodu jej pozbawiono, i zapanuje Boży pokój, miłość, sprawiedliwość i prawdziwa wolnośćc ${ }^{28}$.

25 Tamże, s. 148.

26 Tamże, s. 48-49. Warto wspomnieć, że fragment ten przytoczył Jan Paweł II w homilii wygłoszonej na rozpoczęcie Kongresu Eucharystycznego w Warszawie w czerwcu 1987 r. Zob. Jan Paweł II, Ziemio ojczysta, zjednocz się przy Chrystusowej Eucharystii. Homilia wygłoszona podczas Mszy św. na rozpoczęcie II Krajowego Kongresu Eucharystycznego (Warszawa 8 VI 1987 r.), w: tenże, „Do końca ich umiłował”. Trzecia wizyta duszpasterska $w$ Polsce 8-14 czerwca 1987 roku, Watykan 1987, s. 33.

${ }^{27}$ J. Popiełuszko, Kazania 1982-1984 wygłoszone w kościele św. Stanisława Kostki $w$ Warszawie, s. 96.

28 Tamże, s. 189. 
Na społeczny wymiar nadziei ks. Popiełuszko zwrócił uwagę w jednej z homilii, w której poruszył problematykę wychowania młodego pokolenia. Apelował o to, aby nie zagubić nadziei. Mówił: „W niedalekim zamku car kiedyś krzyczał: »Porzućcie Polacy nadzieję, zamknijcie usta«. Nie zamknęli. Drogo za to płacili, ale nie zamknęli ust swoich i dlatego dzisiaj jesteśmy im wdzięczni, bo to oni przekazali nam ducha narodowego. Jesteśmy spadkobiercami tych, którzy ust swoich nie zamknęli, gdy chodziło o ważne sprawy narodu. Dlatego i my zamykać ust nie możemy, gdy idzie o wychowanie młodego pokolenia, które w niedalekiej przyszłości na swoich barkach poniesie losy domu ojczystego. A wy, drodzy młodzi przyjaciele, musicie mieć w sobie coś z orłów. [...]. Musicie ducha hartować i wznosić wysoko, aby móc jak orły przelatywać ponad wszelkim innym ptactwem, w przyszłość naszej Ojczyzny. Tylko będąc jak orły, potraficie przebić się przez wszystkie dziejowe przełomy, wichry i burze, nie dając się spętać żadną niewolą. Pamiętajcie. Orły to wolne ptaki, bo szybują wysoko, a nie pełzają po ziemi”"29.

Fakt, że duchową sylwetkę ks. Popiełuszki cechuje niezachwiana nadzieja, która określała jego przekonania i była obecna w jego kaznodziejstwie, potwierdza jego śmierć i wydarzenia, które zaszły po niej, związane z pogrzebem, pielgrzymowaniem do jego grobu i w końcu procesem beatyfikacyjnym, a obecnie także kanonizacyjnym. Jak stwierdził G. Weigel, jego postać jest ewidentnym świadectwem tego, że nadziei nie można zamordować ${ }^{30}$.

\section{CZŁOWIEK NIESTOSOWANIA PRZEMOCY I SPRZECIWU WOBEC ZŁA}

Biskup opolski Alfons Nossol w przywołanej już odezwie wystosowanej w związku ze śmiercią ks. Jerzego Popiełuszki zwrócił uwagę na charakterystyczną dla jego postaci i działalności chrześcijańską zasadę non violence, polegającą na zwalczaniu zła dobrem. Pisząc o zamordowaniu warszawskiego kapłana, stwierdził: „Wobec bezprawia i tego rodzaju

29 Tamże, s. 179-180.

${ }^{30}$ G. Weigel, Zeuge der Hoffnung. Johannes Paul II. Eine Biographie, Paderborn 2003, s. 552. 
przemocy oraz zorganizowanej nienawiści rodzi się spontanicznie odruch oburzenia i międzyludzkiej solidarności. Nie kierujmy się jednak uczuciem zemsty i nienawiści. Z prawdziwym niepokojem stwierdzamy w tym przypadku działanie sił nienawiści w naszej Ojczyźnie, które pragniemy pokonać sprawiedliwością, dobrocią i chrześcijańską miłością, ponieważ zło należy zawsze zwyciężać dobrem (por. Rz 12,21). W obronie takiej drogi i takich wartości oddał ostatecznie swoje życie młody kapłan warszawski. [...] Nie nawoływał bynajmniej do okrutnej nienawiści i gwałtu, ale domagał się stanowczo poszanowania godności człowieka, respektowana należnych każdemu człowiekowi praw. Usiłował głosić zasady, które wypływają z Ewangelii, i w ich też obronie w sposób okrutny zginął"31.

Charakterystyczna dla sylwetki duchowej ks. Jerzego Popiełuszki jest postawa niestosowania przemocy i sprzeciwu wobec zła. Sprzeciw w obliczu „potęgi” zła był dla niego zobowiązaniem moralnym, a niestosowanie przemocy chrześcijańskim sposobem wyrażania tego sprzeciwu ${ }^{32}$. Te dwa komplementarne aspekty postawy wobec zła zostały szczególnie wyraźnie wyartykułowane w homilii, którą ks. Jerzy Popiełuszko wygłosił krótko przed swoją męczeńską śmiercią w Bytomiu 8 X 1984 r. Nawiązując do apelu papieża Jana Pawła II z 23 VI 1982 r., aby zło dobrem zwyciężać, stwierdził: „Tylko ten może zwyciężać zło, kto sam jest bogaty w dobro, kto dba o rozwój i ubogacenie siebie tymi wartościami, które stanowią o ludzkiej godności dziecka Bożego. Pomnażać dobro i zwyciężać zło to dbać o swoją ludzką godność. [...] Zachować godność, by móc powiększać dobro i zwyciężać zło, to pozostać wewnętrznie wolnym, nawet w warunkach zewnętrznego zniewolenia, pozostać sobą w każdej sytuacji życiowej. Jako synowie Boga nie możemy być niewolnikami”33.

W tej samej homilii ks. Jerzy Popiełuszko zwrócił uwagę na trzy aspekty powiększania dobra i zwyciężania nim zła. Są nimi sprawiedliwość, prawda i męstwo. Sprawiedliwość wiąże się z miłością, a brak mi-

${ }^{31}$ A. Nossol, Odezwa z 3 XI 1984 w związku ze śmiercia księdza Jerzego Popiełuszki. Podobny wydźwięk ma kazanie wygłoszone przez bpa A. Nossola w katedrze opolskiej 3 XI 1984 r. Zob. A. Nossol, Zwyciężajmy zło dobrem, w: tenże, Miłość zwycięstwem prawdy. Dynamiczny charakter słowa Bożego, Opole 1987, s. 484-489.

${ }^{32}$ G. Weigel, Zeuge der Hoffnung, s. 479.

33 J. Popiełuszko, Słowa do narodu. Kazania i rozważania 1982-1984, F. Blachnicki (oprac.), Carlsberg 1984, s. 127-128. 
łości i dobra prowadzi do nienawiści i przemocy, które są zaprzeczeniem sprawiedliwości. Z tej racji, że źródłem sprawiedliwości jest Bóg, eliminowanie Go z życia społecznego prowadzi do niesprawiedliwości. Istotne jest to, aby każdy w swoim życiu i środowisku kierował się sprawiedliwością, gdyż to bierność moralna $\mathrm{w}$ tym względzie inspiruje niesprawiedliwość i powiększa zło. Pomnażanie dobra i zwyciężanie zła dzieje się przez kierowanie się prawdą i niechęć do kłamstwa. Prawda zespala i jednoczy ludzi, ale też przeraża i demaskuje kłamstwa ludzi małych i zalęknionych. Żyć w prawdzie oznacza być w zgodzie z własnym sumieniem, kłamstwo zaś poniża, jest cechą niewolników i ludzi małych. Człowiek, zdradzając prawdę, zdradza siebie, a ideologie kierujące się kłamstwem i przemocą upadają, przynoszą złe owoce i spustoszenie moralne. Wreszcie warunkiem zdobywania przez człowieka prawdy i zwalczania zła, jakim jest kłamstwo jest męstwo, będące przezwyciężeniem ludzkiej słabości, zwłaszcza lęku i strachü ${ }^{34}$.

W tej strategii zwyciężania zła dobrem niewystarczające jest potępianie zła, kłamstwa, tchórzostwa, zniewolenia, nienawiści, przemocy, ale ważne jest bycie świadkiem, rzecznikiem i obrońcą sprawiedliwości, dobra, prawdy, wolności i miłości. Żądając prawdy, samemu trzeba nią żyć, żądając sprawiedliwości, należy być sprawiedliwym w stosunku do innych, żądając odwagi i męstwa, samemu należy być mężnym i odważnym. Człowiek nie ulęknie się zła i będzie je likwidował ze swojego życia osobistego, rodzinnego i społecznego, kiedy będzie podążał drogą prawdy i sprawiedliwości, zachowa wewnętrzną wolność i godność i będzie budował solidarność serc i umysłów ${ }^{35}$.

Powyższe myśli dotyczące strategii zwalczania zła dobrem zostały wyrażone także w ramach rozmyślań w czasie modlitwy różańcowej, odprawionej w Bydgoszczy 19 XII 1984 r., w dniu uprowadzenia ks. Popiełuszki przez funkcjonariuszy Służby Bezpieczeństwa ${ }^{36}$. Przy rozważaniu tajemnicy ukrzyżowania Chrystusa ks. Popiełuszko sprecyzował to, na czym polega zwalczanie zła dobrem. Powiedział: „Aby zło dobrem zwyciężać i zachować godność człowieka, nie wolno walczyć przemocą.

\footnotetext{
34 Tamże, s. 128-131.

35 Tamże, s. 132.

36 Zob. tamże, s. $142-147$.
} 
Ojciec święty w czasie stanu wojennego w modlitwie do Pani Jasnogórskiej powiedział, że naród nie może rozwijać się prawidłowo, gdy jest pozbawiony praw, które warunkują jego pełną podmiotowość i państwo nie może być mocne siłą żadnej przemocy. Komu nie udało się zwyciężyć sercem i rozumem, usiłuje zwyciężyć przemocą. Każdy przejaw przemocy dowodzi moralnej niższości. Najwspanialsze i najtrwalsze walki, jakie zna ludzkość, jakie zna historia, to walki ludzkiej myśli; najnędzniejsze i najkrótsze to walki przemocą. Idea, która potrzebuje broni, by się utrzymać, sama obumiera. Idea, która utrzymuje się tylko przy użyciu przemocy, jest wypaczona. Idea, która jest zdolna do życia, podbija sobą; za nią spontanicznie idą miliony. Solidarność dlatego tak szybko zadziwiła świat, że nie walczyła przemocą, ale na kolanach, z różańcem $\mathrm{w}$ ręku, przy polowych ołtarzach, upominała się o godność ludzkiej pracy, o godność i szacunek dla człowieka. O te wartości wołała bardziej, niż o chleb powszedni" 37 .

Słowa „zło dobrem zwyciężaj”, które były dewizą życia ks. Jerzego Popiełuszki, sprawiały, że nie było w nim antypatii do osób czy nienawiści do jego oprawców. Był on człowiekiem sprawiedliwym, żył wiarą i miłością, a w swoich kazaniach wzywał do zgody. Miał świadomość, że źródłem zła dyktatury jest szatan, dlatego zachęcał, by je zwyciężać dobrem i łaską Bożą, a jest to możliwe dla człowieka, który jest pełen dobroci. Zło, które niesie ze sobą przemoc, jest oznaką słabości i bezużyteczności, dobro zaś zwycięża i rozprzestrzenia się mocą swojej słodyczy, współczucia i miłości ${ }^{38}$. Jak stwierdził papież Benedykt XVI, „jego ofiarna posługa i męczeństwo są szczególnym znakiem zwycięstwa dobra nad złem"39.

Myśl o pokonywaniu zła dobrem występuje w wielu homiliach wygłaszanych przez ks. Jerzego Popiełuszkę. Prosił m.in. Boga o to, aby narodowi dodał ufności w zwycięstwo dobra nad złem, ale także, aby

37 Tamże, s. 146-147; tę samą myśl wyraził w homilii wygłoszonej 26 XII 1982 r. Zob. J. Popiełuszko, Kazania 1982-1984 wygłoszone w kościele św. Stanisława Kostki $w$ Warszawie, s. 64.

38 A. Amato, Homilia podczas beatyfikacji ks. Jerzego Popiełuszki (Warszawa 6 XI 2010), s. 60.

39 Benedykt XVI, Ks. Popiełuszko przykładem dla księży i świeckich. Rozważanie przed modlitwa "Anioł Pański” (Nikozja 6 VI 2010), OsRomPol 31(2010), nr 8-9, s. 19. 
oświecił zaćmione umysły braci ${ }^{40}$. Najgłębszym symbolem i mocą do przezwyciężania zła dobrem był dla niego krzyż Chrystusa. W homilii z 27 III 1983 r. mówiąc o krzyżu, stwierdził, że jest to „[...] znak zwycięstwa dobrego nad złem, życia nad śmiercią, miłości nad nienawiścią. A dla was, bracia, którzy w sercach chowacie opłacaną nienawiść, niech będzie czasem refleksji, że przemoc nie zwycięża, choć może przez jakiś czas tryumfować. Mamy tego najlepszy dowód spod krzyża Chrystusa. Tam również była przemoc, była nienawiść do Prawdy. Ale przemoc i nienawiść zostały pokonane przez aktywną miłość Chrystusa. Bądźmy więc silni miłością, modląc się za braci błądzących, nie potępiając nikogo, a piętnując i demaskując zło. Prośmy Chrystusa, jako Jego wyznawcy, słowami, które On wypowiedział z krzyża: »Ojcze, odpuść im, bo nie wiedzą, co czynią" (por. Łk 23,34). A nam daj, Chryste, większą wrażliwość na działanie miłości niż siły zła i nienawiści”"41.

Tym powtarzającym się apelom i modlitwom o zdolność do przezwyciężania zła dobrem towarzyszy w kaznodziejstwie ks. Popiełuszki związane $\mathrm{z}$ tą strategią przekonanie o jednoznacznej postawie sprzeciwu wobec zła. Niedopuszczalna jest akceptacja zła czy jego mechanizmów ze strachu i lęku, albo wygodnictwa. W takiej sytuacji człowiek nie ma prawa piętnować zła, którego sam staje się twórcą i pomaga je zalegalizować. Stąd niezbędne jest wyraźne przeciwstawienie się złu nie na drodze przemocy i demonstracji siły, ale przez przezwyciężenie ludzkiej słabości, zwłaszcza lęku i strachu, oraz świadectwo życia w sprawiedliwości, dobru, prawdzie, wolności i miłości. Dopiero wtedy nastaną warunki owocnego budowania i pokój, który nie jest wymuszonym milczeniem ludzi ${ }^{42}$.

O konieczności przeciwstawienia się złu mówił ks. Popiełuszko w homilii wygłoszonej 31 X 1982 r. po kanonizacji św. Maksymiliana Marii Kolbego. Postać tego świętego utwierdza w przekonaniu, że potęga zła, zakłamania, pogardy i nienawiści do człowieka musi zostać pokonana. Jest on symbolem zwycięstwa, jakie odnosi człowiek zniewolony siłą, ale wolny wewnętrznie. Drogą do tego jest życie w prawdzie, świadczenie

${ }^{40}$ J. Popiełuszko, Kazania 1982-1984 wygłoszone w kościele św. Stanisława Kostki $w$ Warszawie, s. 82.

${ }^{41}$ Tamże, s. $87-88$.

42 Tamże, s. 194-195. 
o niej, przyznawanie się do niej i upominanie się o nią, demaskowanie i protest przeciwko zakłamaniu, a także przezwyciężenie lęku w obliczu groźby cierpienia lub utraty jakiegoś dobra na rzecz wyższych wartości. Wzorem takiej postawy jest św. Maksymilian Maria Kolbe ${ }^{43}$.

Te dwie komplementarne względem siebie postawy prowadzą do pojednania, które polega na naprawie krzywd wyrządzonych narodowi i przystąpieniu do wspólnego stołu w celu szukania dróg wyjścia. Pojednanie, które ma na uwadze dobro Ojczyzny i poszanowanie ludzkiej godności, dokonuje się w duchu miłości i sprawiedliwości. Miłość przerasta sprawiedliwość, ale jednocześnie znajduje w niej potwierdzenie. Pojednanie i zgoda nie są jednak tylko deklaracjami. Aby nie przerodziły się w kapitulację i rezygnację z ideałów, tęsknot i wiary w lepszą i godniejszą przyszłość, konieczne są gwarancje, że proces ten nie zakończy się oszustwem i zmarnowaniem ludzkiego trudu i pracy ${ }^{44}$.

\section{4. "CZŁOWIEK BOŻY" ZAANGAŻOWANY SPOŁECZNIE}

Ksiądz Jerzy Popiełuszko był świadomy tego, że kapłan musi być „Człowiekiem Bożym”45. W jego przekonaniu nie oznaczało to jednak ograniczenia posługi kapłańskiej wyłącznie do przestrzeni kościelnej, ale wyjście do świata, zwłaszcza zaś zaangażowanie się w duszpasterstwo ludzi pracy. Wyraża się w tym kolejny rys sylwetki duchowej żoliborskiego kapłana, kapelana „Solidarności”, którego głęboka wiara wiązała się z zaangażowaniem w sprawy społeczne. W jednym z wywiadów, w którym mówił o swoim zaangażowaniu w duszpasterstwo służby zdrowia i środowisk robotniczych, stwierdził: „Praca księdza jest przedłużeniem pracy Jezusa Chrystusa. Ksiądz jest wzięty spośród ludzi i ustanowiony dla ludzi, by im służyć. Stąd też obowiązkiem księdza jest być zawsze tam, gdzie są ludzie najbardziej potrzebujący, krzywdzeni, ludzie poniewierani w swojej ludzkiej godności”46.

\footnotetext{
43 Tamże, s. 54-56.

44 Tamże, s. 87, 217.

45 J. Popiełuszko, Zapiski 1980-1984, s. 29.

46 J. Popiełuszko, Zapiski, listy i wywiady 1967-1984, s. 118.
} 
W trudnych chwilach, jakimi były strajki i internowania, zdaniem ks. Popiełuszki niezwykle ważna była obecność księdza i jego pomoc duchowa, którą jest modlitwa, otwartość, wsłuchanie się w troski i problemy ludzi, ale także pomoc materialna udzielana ludziom najbardziej potrzebującym. Posługa sakramentalna kapłana oraz jego towarzyszenie ludziom w ich troskach i kłopotach codzienności, cierpieniach, których doznają w pracy, więzieniach i na ulicy jest świadectwem tego, że nie są $\mathrm{w}$ tym osamotnieni, a ich zmagania nie są pozbawione sensu. Obecność kapłana niesie ludziom również umocnienie nadziei, utrwala w postanowieniach do rozszerzania braterstwa i solidarności między ludźmi, a także kieruje cierpienia ludzi do Boga i przemienia je $\mathrm{e}^{47}$.

W innym wywiadzie, z 1 V 1983 r. stwierdził wprost: „,...] nie potrafię zamknąć swojego kapłaństwa w kościele, chociaż tylu różnych »doradców « podpowiada mi, że prawdziwy polski ksiądz nie powinien wychodzić poza kościelne ogrodzenie. Będę wśród swoich robotników, dopóki tylko będę mógł..."48. Stwierdzenie to wynikało z jego przekonania, że człowiek odkrywa i doświadcza Boga także poza świątynią, w miejscu swojego zamieszkania, pracy i wypoczynku. Wynika to z nauczania Kościoła o tym, aby modlić się także w pracy i pracą, ale także z przekonań robotników, którzy pragnęli, aby Chrystus i Kościół współtworzył z nimi codzienność pracy, wysiłku i służby na rzecz innych. Owo towarzyszenie Kościoła przez posługę kapłana ludziom w ich codzienności prowadzi do odkrycia i wzrastania w poczuciu ludzkiej godności, poważnego traktowania swojego życia, również ważności jego wymiaru religijnego, ale otwiera także na inne podejście do własności społecznej, wyrażającej się w postawie dbałości o zakład, narzędzia produkcji oraz uczciwości w pracy ${ }^{49}$.

Człowiek wierzący jest świadomy potrzeby zaangażowania w urzeczywistnianie się sprawiedliwości społecznej. Bierność moralna inspiruje niesprawiedliwość. Stąd ważne jest domaganie się sprawiedliwości, która nakazuje kierowanie się dobrą wolą i miłością w stosunku do człowieka, stworzonego na obraz i podobieństwo Boże. Nie można się przy tym ograniczyć do odwagi upominania się o sprawiedliwość, ale należy samemu

\footnotetext{
47 Tamże, s. 118-121.

48 Tamże, s. 110.

49 Tamże, s. 108-109.
} 
być twórcą sprawiedliwości w stosunku do samego siebie, swojej rodziny i środowiska, w którym człowiek żyje ${ }^{50}$.

Ksiądz Popiełuszko był przekonany, że przeobrażeniom społeczno-gospodarczym musi towarzyszyć wiara w Boga. Wykluczenie Boga z życia społecznego prowadzi donikąd. Brak Boga oznacza brak Jego praw, przykazań i mocno zakorzenionej i sprawdzonej moralności chrześcijańskiej. Ścisły związek Boga, modlitwy i pracy pomaga człowiekowi dostrzec sens jego życia i trudu. Człowiek pracy bez odniesienia do Boga, bez modlitwy i bez ideałów, jest podobny do ptaka z jednym skrzydłem, drepczącego po ziemi i niepotrafiącego się wznieść wysoko, by zobaczyć swoje możliwości i sens swojego doczesnego życia. Człowiek bez odniesienia do Boga jest jak okaleczony ptak, krążący wokół własnego dzioba. Dlatego ważne jest otwarcie na Boga bram fabryk, warsztatów, klinik i różnych miejsc pracy, co zapewni im nowe życie. Wówczas praca człowieka stanie się czynnikiem, który go ubogaci i uszlachetni, a sam człowiek nie będzie traktowany jak robot, który ma obowiązek realizowania planów tworzonych przez teoretyków. Wówczas nastąpią właściwe proporcje między materią i tym, co duchowe, a człowiek pracy, który ma uszlachetniać materię, sam będzie uszlachetniał się przez wykonywaną pracę ${ }^{51}$.

W homilii wygłoszonej 29 stycznia 1984 r. ks. Popiełuszko, przypominając o godności ludzkiej pracy i domagając się prawa do odpowiednich warunków pracy, stwierdził: „Nie jest rzeczą najważniejszą, aby człowiek w krótkim czasie zrobił wiele, ale by przez długi czas dobrze pracował. Można człowieka poniżyć, można odebrać mu godność również i przez pracę, gdy uczyni się go tylko narzędziem produkcji, gdy nadmierne bodźce pobudzają do nadmiernego wysiłku z pogwałceniem ładu Bożego. A cywilizacja o profilu czysto materialistycznym czyni człowieka niewolnikiem wytworów i obdziera go z jego prawdziwej wartości. Nie wolno nam zapominać prawdy, że dla zachowania wiary i godności można poświęcić nawet wolność, ale dla zachowania wolności nigdy nie wolno poświęcić wiary i godności dziecka Bożego" ${ }^{52}$.

${ }^{50}$ J. Popiełuszko, Kazania 1982-1984 wygłoszone w kościele św. Stanisława Kostki $w$ Warszawie, s. 202-206.

51 Tamże, s. 91-92.

52 Tamże, s. 170. 
Wielokrotne przywoływanie przez ks. Jerzego Popiełuszkę myśli kard. Stefana Wyszyńskiego świadczy o tym, że był on pod wyraźnym wpływem nauczania Prymasa Tysiąclecia, który podkreślał potrzebę przenikania duchem ewangelicznym problemów świata doczesnego i był świadomy szczególnej roli, jaką mają w tym względzie do odegrania kapłani. Powołanie kapłańskie jest darem otrzymanym nie dla siebie, ale dla służby Bogu i ludziom. Istnieje ścisły związek między ewangelizacją i osobistą postawą kapłana, co sprawia że głoszenie Ewangelii ma prowadzić do całkowitego oddania się Bogu i ludziom aż do ofiary swojego życia ${ }^{53}$. Jednocześnie z tej nadrzędnej nadprzyrodzonej cechy posługi kapłańskiej wynika jej aspekt społeczny, który oznacza zaangażowanie się w aktualne sprawy życia i występowanie w obronie godności człowieka i jego spraw gwarantujących mu godziwą egzystencję.

Powyższe refleksje w sposób syntetyczny przedstawiają podstawowe rysy sylwetki duchowej bł. ks. Jerzego Popiełuszki. Na ich sformułowanie pozwalają zachowane zapiski i wywiady, wygłaszane homilie i rozmyślania, a także świadectwa osób i dostępne biografie. Najogólniej można stwierdzić, że specyficzna duchowość tego kapłana obejmuje odniesienie do Boga i związane z nim formy religijności, ale także wynikającą z tego postawę odpowiedzialności za naród i jego przyszłość oraz nieustraszoną służbę na rzecz godności człowieka. Choć wskazane rysy duchowości w dużej mierze wiążą się z działalnością kaznodziejską ks. Jerzego Popiełuszki, to zawarte tam myśli nie są jedynie ogólnymi sformułowaniami z nauczania Kościoła, ale wyrażają jego przekonania, a męczeńska śmierć potwierdza wierność głoszonym prawdom. Męczeństwo ks. Jerzego Popiełuszki i jego postawa wierności aż do śmierci uzasadniają słuszność poszukiwań rysów jego sylwetki duchowej w tym, co głosił. Zwłaszcza jego homilie, które rodziły się w konkretnym kontekście społeczno-historycznym i zawierają odniesienia do czasu stanu wojennego, zawierają także liczne myśli o charakterze ponadczasowym i dlatego mogą stanowić podstawę dla aktualnej refleksji z zakresu duchowości chrześcijańskiej i jej podstawowych elementów.

${ }^{53}$ P. Nitecki, Znak zwycięstwa, s. 34-35. 
Streszczenie. Postać bł. ks. Jerzego Popiełuszki doczekała się już kilku poważnych opracowań, przedstawiających jego biografię. Również akta z procesu dotyczącego jego zamordowania przedstawiają różne wątki z jego życia i charakteryzują jego postać, a także wydarzenia z jego życia. Biografia i faktografia dotyczące jego osoby, na którą składa się wiele wątków i świadectw, jest mocno złożona. Inną ciekawą, aczkolwiek podobnie złożoną kwestią, jest adekwatne przedstawienie sylwetki duchowej znanego na całym świecie kapłana zamordowanego przez funkcjonariuszy Służby Bezpieczeństwa. Nie pozostawił on po sobie testamentu duchowego, a zapiski i kazania, zawierające wiele oryginalnych myśli, pozwalają jedynie pośrednio na zarysowanie istotnych cech duchowości ich autora. $\mathrm{Na}$ fakt, że postać bł. ks. Jerzego Popiełuszki charakteryzuje specyficzna duchowość, wskazują słowa Jana Pawła II wypowiedziane 7 czerwca 1991 r. we Włocławku, który określił go biblijnym stwierdzeniem „człowiek wewnętrzny”. Niniejszy artykuł syntetycznie ukazuje wiodące i specyficzne rysy sylwetki duchowej bł. ks. Jerzego Popiełuszki, jakie wyłaniają się z analizy jego życiorysu, zachowanych notatek, udzielonych wywiadów i wygłoszonych homilii, a także świadectw o nim osób, które go znały. Do istotnych elementów sylwetki duchowej tego bohaterskiego kapłana należy jego postawa głębokiej wiary i zawierzenia Bogu, niezłomnej nadziei, niestosowania przemocy i sprzeciwu, a także społeczne konsekwencje wyznawanej wiary.

Słowa klucze: ks. Jerzy Popiełuszko; duchowość; niestosowanie przemocy; religijność; wiara; nadzieja.

Summary. Main qualities of spiritual profile of blessed father Jerzy Popiełuszko. There are many serious studies dedicated to the person of blessed father Jerzy Popiełuszko that describe his biography. The acts of the lawsuit regarding his murder by the officials of the State Security Service describe different thems of his life and describe his person and facts of his life. His biography is many-sided. Another interesting and many-sided question is the presentation of spiritual profile of that famous, in the whole world, Polish priest, who lived in the second half of the 20th century. He did not leave any spiritualtestament, and his memoire and sermons, that contain many interesting thoughts, only indirectly describe his main spiritual specific traits. John Paul II during his trip to Poland in 1991 said in Wloclawek (7 June) that father Jerzy Popieluszko may be characterised by a biblical expression, an "inner man". This article presents main qualities of spiritual profile of the blessed Jerzy Popiełuszko, that appear from the analysis of his biography, memoires, interviews, sermons, and testimonies of those who knew him. His martyrdom, attitude of a strong faith, confidence to God, and fidelity until death justify our search for his spiritual profile in all what he preached.

Keywords: father Jerzy Popiełuszko; spirituality; non violence; religious live; faith; hope. 
